\title{
THE PRINCIPLE OF EXHAUSTION OF RIGHTS IN TURKEY*
}

\section{Selin ÖZOĞUZ**}

\section{Abstract}

The main aim of this article is the application of the principle of exhaustion of rights in Turkey. The principle of exhaustion of rights plays an important role in the parallel import of patented or trademarked goods. It is a subject that concerns intellectual property rights (IPRs) and competition law. That is why it is an issue of interest particularly for the licensing and thereby the transfer of technology and its regulation, which is an area of which IPRs and competition law come together. The discussion is based on which type of the exhaustion of right principle has been applied in Turkey and the legal problems thereupon. It is of vital importance to clarify the existing legal uncertainty in this area; consequently uniform decisions can be given by the legal authorities on important trade related issues. Firstly, an explanation of the principle of exhaustion of rights and its differing types will be given. Then varying arguments on which type of the exhaustion of rights principle is and should be applied will be discussed based on different authors. Examples of cases by the legal authorities will follow to elucidate the subject further. Finally, suggestions will be given supported by the deductions made throughout the discussions.

" The point of departure of this study is the author's $\mathrm{PhD}$ thesis entitled "Regulation of Technology Transfer in the European Union and Turkey", which she successfully defended at the EC Institute in the year 2004.

* Dr., European Union Law 
The concepts of technology and its transfer gained importance after the globalisation of the world economy. Technology and knowledge are the main drivers of economy today. Therefore, the regulation of technology transfer throughout the world became a crucial issue.

The aim of the regulation of technology transfer is the creation of a favourable legal environment for development of technological innovation and its dissemination, while ensuring the protection of intellectual property rights (IPRs), which bear the content of technology in the industrialised world, and a healthy functioning of the competition in the markets.

IPRs provide incentives for innovative efforts and their dissemination and commercialisation by establishing enforceable property rights for the creators and producers of new and useful products, more efficient processes and original works of expression. Competition law promotes innovation and consumer welfare by prohibiting certain actions that may harm competition. The question that bears relevance for the issue of technology transfer is what level of IP protection is sufficient to create a substantial incentive to innovate, without creating rights to exclude so broad as to impair competition. In a way, technology transfer block exemption regulations' aim is to keep the outcomes of the respective laws in balance. One of the main balancing mechanisms in this area is the principle of the exhaustion of rights created by the European Court of Justice (ECJ), which we will elaborate further below. The main aim of this article is to analyse the principle of exhaustion of rights in Turkey in terms of competition law, laws concerning intellectual property rights and international trade relationships.

The economic and social effects of globalisation are important reasons for the legislative enactments and amendments in Turkey. Yet another main important reasons for immediate impositions on the legal system of Turkey are the World Trade Agreement (WTO), offspring of GATT, which came into effect on January 1, 1995, and the Customs union with the EU, which came into effect January 1, 1996.

Turkey is in the process of adjusting its legal structure to comply with the international treaties it has entered into. The amendments concerning our subjects, IPRs and competition law are mainly based on the laws of the EU, primarily because of its obligations as the result of the Customs Union, but also because of its desire for full accession to the EU. A large number 
of arnendments have already been made in terms of laws, decrees and regulations. A technology transfer block exemption regulation is one of the regulations to be adopted within this context.

The Turkish Competition Authority has produced a draft of technology transfer regulation that has not yet been issued. The draft is based primarily on Technology Transfer Block Exemption (TTBE) 240/96 of the EU. This means that the draft regulation does not contain the modifications brought about by the issuance of the TTBER of May 2004. There are also other issues that create confusion in this area. These areas of conflicting nature are concerned with the wordings of various laws, which do carry relevance in the matter of a technology transfer regulation. This situation leads sometimes to diverse outcomes in terms of the decisions in the courts. Having such diverse outcomes are unacceptable. Consequently, it is necessary to consider the related laws regarding the issue of technology transfer, and where there are areas of conflict, the necessary modifications should be made to the corresponding laws, decrees and regulations. The desired outcome is to have a uniform decision when all the laws have been considered collectively.

There are several issues to be examined in regard to the formation of a new technology transfer block exemption regulation. One of the important subjectsand an area that could be the cause of problems in application is the "parallel import". The situation in both Turkey and the EU is that the prevention of parallel import through the use of IPRs is forbidden. Competition law defends the viewpoint that it is a requirement of the free market economy that parallel import be unrestricted. The judgments based on the "principle of exhaustion of rights" developed by the ECJ are considered by the Commission to be the most important elements in ensuring the protection of parallel import as a balance against regional restrictions.

The ECJ has made a number of decisions with respect to the exhaustion of rights principle. We will not go into detail of the example cases of the $\mathrm{EU}$, since the concern of this article is the jurisprudence in Turkey. According to the results of the decisions in these cases, it is clear that the EU supports the principle of regional exhaustion of rights. Namely, the IPRs are exhausted within the borders of the EU. But when we look at the case of Turkey in this regard, in different laws and decrees which kind of the principle of exhaustion of rights is chosen is not clear, which again gives way to different interpretations in this matter. However, it is clear that all of 
the relevant laws should be ordered in such a manner that uniform decisions could be reached. In order to prevent the current confusion, all the applications must be brought into agreement in order to lead to the same results and conclusions. In order to clarify the situation in Turkey, we will give some examples of cases that have been brought to court up to this point in time. Likewise, it is clear that authorities on the subject hold considerably varying views.

The principle of exhaustion of rights of IPRs clearly delineates the right of the owner to manufacture and first sale. With respect to the goods covered by the IPR principle, from the first time that the owner of the rights or his licensed third party presents his goods to the market their rights are considered exhausted. Once the goods have been marketed for the first time, the owner of the rights can no longer claim any right to control over a third party who offers these goods to the market again. The ECJ set out the principle of exhaustion of rights. This states that an IP owner's rights to control a product's distribution only apply until that product is sold either by the IP owner or with its consent. ${ }^{1}$

In other words, this means that as the result of the subject of the IPR having been offered by consent to the market, its IPR is considered exhausted and the property is subject to the rules of trade rather than the rules of IPR. ${ }^{2}$ The term exhausted is used because the owner of the rights to the IPR for his product is deemed to have received the reward for the creative, innovative effort expended, and the authority given to him by IPR expires when he first puts it on the market. This argument is particularly frequently used as the justification for decisions made by the ECJ.

The principle of exhaustion of rights can be divided into three different categories, which find applications in different countries. These are designated as national, regional and international exhaustion. The adoption of the exhaustion principle at the national level is the most protective of these approaches. Accordingly, the adoption of the principle of international exhaustion of rights represents the most liberal view from an economic standpoint.

1. National exhaustion: When the exhaustion of IPRs is accepted only within the boundaries of one nation, it is known as the principle of national exhaustion. In this situation, the owner of the right will not exhaust his IPR on products offered to the market 
outside of his own country. Even when they are the original products, the IPR owner can prevent them from being imported to his country. The exception to this is re-import. In re-import, the product is first offered to the national market and the product which has been marketed is later exported to another country. Re-import occurs when these original products, which have been exported, are brought back to the country of origin by a third party.

2. Regional exhaustion: If the countries which are included within the boundaries of a region composed of more than one country accept exhaustion for this region it means that they accept the principle of regional exhaustion. In this situation, while parallel import is possible among the nations that belong to the region, parallel import is not possible for nations outside the region. It appears that the EU has adopted this regional exhaustion of rights.

3. International exhaustion: When nations do not acknowledge any boundaries, they are said to have accepted the principle of international exhaustion. Under these circumstances wherever the products are legally marketed these products will be considered to have exhausted their IPRs.

As mentioned previously, there are many different views as to which of the exhaustion principles is preferred in Turkey. These differing viewpoints manifest themselves in different laws. Actually, in order to be able to understand which of these views should dominate in Turkey, it will be useful to take a look at the arguments and laws which constitute and represent the varying points of view.

According to Arikan, the principle of "national exhaustion" prevails in Turkey. The foundation of the arguments around which Arkan's viewpoint developed can be found in Patent Decree No. 551, Article 76. According to this article: "The patented product and any deeds related to it, after having been presented for sale by the patent holder or the person presenting the products for sale in Turkey with its permission, are outside the scope of the rights originating from the patent".

The basis of the law is both secondary law of the EU and it is also expressed in the Community Patent Convention. During the preparatory work for the decree, the phrase, "in the Community" in the EU secondary arrangements was replaced by the phrase, "in Turkey". By this decision, 
Turkey accepted the right of the patent's "exhaustion principle in Turkey", that is, the principle of national exhaustion." "Under these circumstances, in Turkey the owner of the IPR should be able to prevent the import of original products that arrive in the country via parallel import.

According to this view, the applications that will be valid in Turkey should be as follows: the rights that are acknowledged to the owner of the IPR should apply within the geographical boundaries of the country, and result in their having no influence outside its borders. The product has no boundaries but the authority is national. Accordingly, there are as many patent rights as there are countries in which a patent is obtained. Traversing the boundaries in this manner, the patented product which enters a second country, even though the owner of the patent right is the same as in the country it comes from, the result of the exhaustion principle applied is left behind there. The product is faced with the rights or absence of rights of exhaustion that are recognized by the authority of the country that the product enters. When a product enters the market of a country with the consent of the patent holder, it exhausts its patent rights. The only circumstances which would be an exception is the case of re-import, as mentioned earlier in the explanation of the types of principles of exhaustion. ${ }^{5}$

There is an important point to be mentioned here. Confusion exists in terms of the goods that are presented into the market for the first time. Some commentators on this subject take the goods as the ones bearing the patent or trade mark, while others take the goods as those specific ones, which are presented with the exact amount.

The clarity on this subject comes from Kayhan, who argues that in the case of the acceptance of the principle of national exhaustion of rights, the IPR is only exhausted for the specific amount of goods that are presented in Turkey. The right holder cannot have power over the distribution of these goods within the country, in other words he cannot have control of the goods being the subject of domestic trade issues. Again in the same manner, when those specific goods that are presented into the domestic market for the first time by the right holder are exported to another country and afterwards imported to the country of origin by a third party without the consent of the right holder is considered permitted. ${ }^{6}$ 
On the other hand, in the case of the right holder presenting some of the goods in the domestic market (country of origin) and others in another country the situation is different. In this case the right holders right over the goods in the foreign country is not exhausted. He can prevent a third party from importing the goods into the country of origin based on his rights, so parallel importation is not possible.

Another point that needs clarification again in the case of the acceptance of the principle of national exhaustion of rights is, if the right holders rights are exhausted when he does not present the goods in the country of origin but he does so in another country. Considering the above mentioned explanation on the exhaustion of rights only for specific amount of goods that are presented, it is concluded by Kayhan that the right holder can prevent the parallel importation of the goods into the country of origin that are presented in another country, even if he did not presented the goods in the country of origin, because his rights are considered to be exhausted only for those specific goods that are presented in the country of origin, if there were any. ${ }^{8}$

However, with respect to the adoption in Turkey of the principle of national exhaustion of rights, this needs to be carefully evaluated in the light of Turkey's relationship and commercial partnership with the EU. As mentioned earlier, the EU has accepted regional exhaustion of rights. This has connotations for Turkey. This subject has been evaluated by Pinar after a study of the agreements that were reached during the development of relations between Turkey and the EU. ${ }^{9}$ When the boundaries of the European Economic Area (EEA), are considered to include members of the Community, Iceland, Lichtenstein and Norway, then the same nations are included in the boundaries of the regional exhaustion principle. The justification for this is included in the EEA Agreement, Article 6, and in the arrangements related to IPRs contained in Article 2 of the $28^{\text {th }}$ Protocol of the Agreement.

Pinar arrived at his conclusions through a comparison of the decisions and accords made between Turkey and the EEA Agreement and Community. Accordingly:

- Article 6 of the EEA Agreement brings an arrangement similar to Article 66 of the Association Council Decision No: 1/95. According to both articles, provisions made between the parties, to the extent that they are similar to the Community law decisions 
founding the European Community, are subject to interpretation according to the decisions of the ECJ.

- Contrary to Annex 8, Article 10(2) of the Association Council Decision No: 1/95, in $28^{\text {th }}$ Protocol Article 2, Paragraph 1, states that are a party to the EEA Agreement have accepted the principle of exhaustion of IPRs.

The problem here is that, although the EEA Agreement has been accepted, the exhaustion principle had not been envisioned between the EU and Turkey in the Association Council Decision No: 1/95. It is necessary to consider legal developments in the light of the relevant decisions between the E.U and Turkey and the free movement of goods under Turkish law when making this evaluation.

According to Article 22 of the Association Agreement, the Association Council has the authority to make decisions in situations where it envisions that the purpose is to achieve goals that are stated in the Agreement. According to this association, law is primary when constituted from the Association Agreement and the Additional Protocol; on the other hand Association Council decisions within this framework form secondary legal arrangements. As a result, decisions that are a part of secondary law cannot limit the arrangements that result from primary law. ${ }^{10}$

Additional Protocol Article 29 has been ordered exactly according to the Community Agreement Article 30. The second sentence of this article provides the source of the exhaustion principle. By means of this sentence, arrangements made in EU law Article 30 or the Additional Protocol Article 29 related to preventive measures made for just cause are expressly forbidden to be used as a vehicle for arbitrary discrimination or for disguised trade restrictions. According to the Community Agreement the quantitative restrictions on imports and all measures having equivalent effect are prohibited between Member States, but Article 30 states that these kinds of provisions of the Agreement "should not preclude prohibitions or restrictions on imports, exports or goods in transit justified on grounds of public morality, public policy or public security; the protection of health and life of humans, animals or plants; the protection of national treasures possesing artistic, historic or archeological value; or the protection of industrial and commercial protperty." The second sentence of this Article, which constitutes the source of the exhaustion of rights principle states that: 
"Such prohibitions or restrictions shall not, however, constitute a means of arbitrary discrimination or a disguised restriciton on trade between Member States."

Within the Customs Union, parallel import is only possible if the principle of exhaustion of rights is accepted. However, in Association Council Decision No: 1/95 Annex 8 Article 10(2) it states that this principle was not envisioned between the Community and Turkey. The second paragraph of this Article thus is contrary to Joint Council primary law and constitutes a diminishment of the jurisdiction of this primary law. Consequently, the application of this decision is not possible. ${ }^{11}$

Bearing in mind the primary and secondary legal applications mentioned above, the conclusions are as follows:

- After the Additional Protocol signed in 1972, no type of restriction developed by a member nation of the Community restricting quantity nor any precaution having an equivalent effect can be applied in the case of the import of goods into a member state from Turkey.

- The absence of the acceptance of the principle of exhaustion that is a condition of parallel import of goods between the Community and Turkey is a clear contradiction of Additional Protocol Article 29.

In light of the arguments given above, Pinar concluded that the regional exhaustion of rights that is valid according to Community law becomes valid when the borders of Turkey are included in the resulting wider region. This determination makes parallel import of goods according to appropriate Turkish marketing procedures possible for Community member states. ${ }^{12}$

In order to reach a conclusion with respect to the exhaustion principle in Turkey, it is necessary to study the current laws in effect in Turkey that regulate this subject. In Arrkan's interpretation mentioned above, the Patent Decree No: 551 was presented as the source of the national exhaustion of rights principle. Apart from this, case decisions related to this subject have provided examples of problems arising from this confusion. Consequently, by analysing case decisions made with respect to this subject it will be possible to reach a conclusion about the validity of these articles of law. However, as mentioned earlier, there are striking contradictions in the judicial decisions. 
One of the first of these cases was the Police ${ }^{13}$ decision. The Turkish company SESA Diş Ticaret Limited Şirketi (SESA) is the distributor in Turkey and holds exclusive license rights to the Police, Sting and Vogart trademarks officially registered to the Italian company De Rigo SPA. The defendant Hekim Optik İthalat İhracat Limited Şirketi (Hekim Optik) imported to Turkey the 1996 and 1997 Police trademark eyeglasses and presented them for sale on the market in Turkey. Upon the complaint of the plaintiff SESA, it was established that there was no difference in the eyeglasses marketed by both plaintiff and defendant. It was determined that Hekim Optik had imported to Turkey the identical Police trademark eyeglasses, that is originals, from a foreign country.

The plaintiff contended that he was the only person authorized to import and market Police trademark eyeglasses in Turkey, and that because, without his permission, the relevant product could not be sold or distributed in Turkey, the defendant had violated his trademark rights and that this constituted unfair competition.

Whereas, the defendant responded that he had acquired the original Police trademark eyeglasses from the Police trademark distributor Soon Lee Optical Company which operates in the Singapore Free Trade Zone, and that he had imported them according to the appropriate import procedures and within the framework of the customs laws of the country, had paid all applicable taxes and expenses.

A similar decision was presented to the Court of Cassation (Yargitay): The plaintiff maintained that because of the technical assistance and licensing agreement he held with the Lancome ${ }^{14}$ company, he was the sole authorized party for the import, manufacture and sales in Turkey of all perfume and cosmetic products bearing the Lancome trademark, and that as a result of distribution contracts concluded with third parties, those franchise holders could only sell the Lancome trademark products in their own stores and only make retail sales. In spite of the fact that there was no distribution agreement between the plaintiff and the defendant, the plaintiff maintained that the defendant was wrongly, unjustly and illegally selling Lancome trademark products in his stores at a price below the retail price, and that because of these actions the defendant caused the plaintiff and his franchises to suffer loss. The plaintiff claimed that the sale, distribution and marketing of Lancome trademark products without his permission as the sole authorized party and the failure of the defendant to disclose where and 
how he obtained these products constituted a violation of his trademark rights.

Whereas, the defendant claimed that some of the products in his shop were left over from the previous period when he was a franchisee; that he sold products in his shop that he had purchased from authorized franchisers; and that the products he sold in his shop were original products imported by the plaintiff, and formally requested that the case be rejected.

Two additional cases that came before the Court of Cassation are almost identical to these two. These are the Dexter and NafNaf decisions. The Court of Cassation responded to all four cases in the same manner. When the cases were originally tried in the courts of first instance, they were all considered as constituting unfair competition. Court of Cassation overturned all the decisions of the courts of first instance on the same grounds. Court of Cassation approached the legal implications of the incidents from different directions, based on articles of different laws. These were based on Decree with the Force of Law Concerning the Protection of Trademark Rights No: 556 (Trademark Decree No: 556), Law of Obligations and evaluations from the viewpoint of unfair competition. ${ }^{15}$

Trademark Decree No: 556, Article 13 states that: "after the trademarked goods have entered the market by either the trademark owner or with his consent, the trademark owner cannot forbid the use of the trademark in connection with the use of these products". This is known in practice and in legal arrangements as the exhaustion of trademark rights. In order to apply this principle, the goods bearing the officially registered trademark must be offered to the market in Turkey by the trademark owner or with his consent.

The Court of Cassation took the position that the import or export of goods that have never been offered to Turkish domestic markets can constitute an infringement of trademark rights. But the Court specified that discussion would be required to clarify the situation that would take place if, after the owner of the trademark or a seller with his consent or an exclusive licensee has imported and presented the product to the Turkish market, a third party imports the same trademarked product. From here, the Court of Cassation then took into consideration the authority of the Trademark Decree No: 556 Article 13(1). As a result, they concluded that if the same products as the plaintiff's, that is, original products and not a copy, are produced legally in countries other than the country of origin and imported 
to Turkey from those countries, and thence sold by the importer or purchased against a legal receipt from the importing firm and presented for sale, this would not constitute a violation of the trademark rights.

When the Court of Cassation adjudicated the subject of the cases from the aspect of Law of Obligations, they arrived at the following conclusions: The Court first considered the concept of the exclusive seller and according to the principle of proportionality of contracts, found that this did not involve any obligation or liability for third parties. Because, giving the exclusive seller in the region a monopoly right is solely the responsibility of the owner. This means that only parties who have participated in an agreement, that is, the licensor and licensee, possess the authority to sue one another. Under these circumstances, the exclusive seller cannot use this right to protect himself from third parties by using the unfair competition rules.

Also, when the Court of Cassation evaluated the situation from the viewpoint of unfair competition, they stated the following opinions in an addition to the above-mentioned thoughts: It is not possible according to the rules of unfair competition for the exclusive seller who creates a market by advertising and provides repair and maintenance to prevent vendors from selling the same goods obtained by legal means from countries other than the country of origin in original form. The Court of Cassation opinions have followed this line of thought since 1992.

Of the decisions above, the Police decision and a similar one, the Armada ${ }^{16}$, came before the Competition Board as well. In these decisions, the Competition Board did not reach conclusions different from those of the Court of Cassation. These decisions are important ones from the point of view of the principle of exhaustion of rights and parallel import. For this reason, it will be useful to examine the opinions of the Competition Board in this matter.

A consideration of the Competition Board decisions lead to the following conclusions: The Competition Board does not have authority of repeal of a court decision from the point of view of its legality. Justly, the Board did not make a decision contrary to that of the Supreme Court in the Police case. Even if there had not been a prior decision, when a case is similar to others with the same characteristics, the Board makes a decision parallel to its prior decisions. An example of this type of decision is the 
Armada case, which was similar to the Police decision and did not come before the Court of Cassation. ${ }^{17}$

Earlier, regarding the principle of exhaustion of rights and the consequent topic of parallel import in Turkey, two viewpoints based on the theory of the principles were discussed. The first of these is the national exhaustion principle based on Patent Decree No: 551, and the other is the regional exhaustion principle, which is based on the Customs Union Turkey entered with the EU. However, when we examine the decisions of the Court of Cassation and the Competition Board, we see that in cases concerning the exhaustion principle and parallel import, confusion reigns regarding the laws consulted in order to make a decision.

When we look at the decisions of the Court of Cassation parallel imports are allowed when the importation is made in a legal way, which means when the goods are not counterfeit and the import procedures are complying with the rules of customs law. Accordingly, it follows that the Court of Cassation seems to apply the principle of international exhaustion of rights, although it also points to the fact that national exhaustion of rights is accepted by the Patent and Trademark Decree laws.

The simultaneous acceptance of both national and international exhaustion rights constitutes a contradiction. Aslan has presented a line of thought that brings some enlightenment to this contradiction. The exhaustion of rights doctrine appears to have been accepted through Patent Decree No: 551 Article 76, as well as Trademark Decree No: 556 Article 13. In reality, according to Patent Decree Article 76, "Any actions related to the patented products sold in Turkey by the patent owner or with his consent, remain outside the scope of the patent right"; moreover, the title of the Article is, "Exhaustion of Rights Arising from the Patent". In the same manner, Article 13 of Trademark Decree No: 556, bears a similar assumption. Thus, even though the relevant IPRs have been granted to parties that are active in several regions, the sale of their products by third parties in their regions cannot be prevented based on their IPRs. ${ }^{18}$

It would appear from the above-mentioned articles that the doctrine of exhaustion of rights has been accepted only with respect to goods that have been legally marketed in Turkey. However, this is deceptive, because in order for the import of products protected by a patent or a trademark to be considered a violation, the product must be a counterfeit and the importer must be aware of this. In fact, Patent Decree No: 551 Article 136 items (b) 
and (c) mention that in order to prevent import, the product must be a counterfeit or the patent holder would not have given consent. When we evaluate these two paragraphs together with Article 76, we see that one cannot prevent the sale by third parties of goods that have been legally produced and imported, by using patent rights which are valid in Turkey or in any other country. Similarly, one must evaluate the exhaustion of rights mentioned in Article 13 of Trademark Decree No:556 with the related rule in the same Decree Article 61. According to Article 61, in order to use the trademark rights to stop the sale of goods that have been imported, the imported goods must have been produced illegally. In other words, it is not possible for the trademark owner in Turkey to prevent the sale of goods imported to Turkey that have been legally marketed in a country other than Turkey under the same trademark, that is, original products. ${ }^{19}$

The results of the above-mentioned study of the Patent and Trademark Decree No: 556 decisions with respect to the principle of exhaustion of rights and parallel import make it clear that Turkish law has embraced not the national but the international principle of exhaustion of rights. ${ }^{20}$

However, as we mentioned earlier, according to the agreement governing relations between the licensor and the licensee of the IPRs, they may sue one another on the grounds of violation of contract. From the point of view of Turkish contract law, there is no contract relationship between a third party and the exclusive seller (or licensee, if the contract is not jist a distribution contract but an exclusive licensing agreement) whose monopoly right has been violated, or with the producer (the licensor when it is the case of a licensing) whose distribution system has been adversely affected. For this reason, one cannot bring a case against a third party by using contract law as a basis. This is the result of the principle of proportionality of contracts. $^{21}$

Viewpoints which support the national exhaustion of rights in Turkey argue that the IPR owner can prevent the import of IPR goods, if those goods have not yet been marketed by the patent owner or with its consent in Turkey, even if they have been marketed outside Turkey by the patent owner or with his consent. That means that the IPR will not have been exhausted in Turkey, and the IPR goods in question cannot be imported to Turkey from the foreign country where they have been marketed. ${ }^{22}$ 
According to Aslan's viewpoint here, it is necessary to look at the principle of exhaustion of rights within the framework of Article 176 and Article 61. According to these articles, it is not possible to talk about the importer's illegal use of its IPR products. The importer is not using the IPR goods; he is only importing IPR goods produced in a legal manner, according to customs regulations. Import does not mean that the goods subject to IPR are being illegally used. Erroneous judgements on this subject are the result of a misunderstanding of the principle of "first sale", which is at the core of the principle of exhaustion of rights. The IPRs ensure a monopoly to the owner, but this is not a monopoly without limits. It gives it the authority to submit the goods to the market for the first time by itself or with its consent; that is, it gives the authority to control. However, it does not give the authority to control the movement of the goods thereafter. ${ }^{23}$

When we look at the opinions mentioned above, we see that three types of exhaustion rights seem to have been approved in Turkey. However, it is imperative to accept one of them in order to arrive at uniform decisions. Since both competition law and liberal economy support parallel import, consequently national exhaustion of rights is not a possibility. It is only with the acceptance of either the regional or the international exhaustion of rights principle that parallel import is possible.

In Pinar's interpretation of the principles of regional and international exhaustion, he explains the reasons for preferring the regional exhaustion of rights for Turkey as follows: The arrangements made on the subject of IPRs under Turkish law originated by bringing these laws into harmony within the framework of the Customs Union regulations. Consequently, according to Pinar, when one interprets these laws, one should interpret them in such a way as to serve the purpose of realising the goals of the Customs Union. Otherwise, the free movement of goods is endangered. ${ }^{24}$

Turkey has made changes in its laws on the subject of IPRs not only because of the Customs Union with the EU, but also because of the WTO's GATT and its TRIPS annex. As a result, the new legal arrangements being made in Turkey are not simply related to their function within the Customs Union, but with its global trade as well. It is for this reason that regional exhaustion of rights would be insufficient. Together with Turkey's strategic location and the international agreements it has entered, it is in a situation of open trade with countries outside the European Union as well. It is for this 
reason that, in our opinion, the adoption of the international exhaustion of rights principle appears more appropriate.

Additionally, when we look at the ECJ rulings to date with respect to the $\mathrm{EU}$, we see that, although the principle of regional exhaustion of rights has been accepted, there is a movement toward international exhaustion of rights within the EU as well.

The issue of international exhaustion has attracted much attention in recent years in the Community law. The extension of the products outside the EC or the EEA is an important topic that has to be considered. Parallel importers may be able to buy cheap trademarked goods in a third country and try to import them into the Community. The question is whether a trademark owner within the Community can bring an action under domestic law to prevent such imports, or whether Community law should extend the principles discussed in this section to sales by consent on markets outside the Community. From the consumer's point of view international exhaustion might lead to lower prices, perhaps considerable so. ${ }^{25}$

The Davidoff case from the EU is one in which there was a contrary judgment to the one in the Silhouette case, in which the ECJ concluded that the right of IP has not exhausted for the goods imported from third countries outside the EU. In contrast, in the Davidoff case, the ECJ was saying that the effect of the Trademark Directive was that a Member State cannot impose international exhaustion upon a trademark owner; however, if the proprietor of a trademark agrees, either expressly or otherwise, to allow the entry of goods marketed in a third country into the Community, he cannot then use the trademark to prevent this from happening. This was an important judgment indicating that it might be possible to avoid the apparent logic of Silhouette, with the result that parallel imports from third countries might be allowed. ${ }^{26}$ The narrow interpretation of the Silhouette case is important, although it cannot be said that the EU has adopted the international exhaustion of rights as a rule, this later case shows the tendency of a shift to international exhaustion of IPR in the EU.

For all the reasons given above, it would appear that it is more appropriate for Turkey to take the principle of international exhaustion of rights as a basis. As for the articles also mentioned by Aslan which are responsible for causing contradictions in case judgments, namely Patent Decree No: 551 Article 76 and Trademark Decree No: 556 Article 13, from 
the viewpoint of harmonizing them with other articles of the respective decrees, it is necessary to rearrange them so as to bring them in line with the principle of international exhaustion.

Concerning the situation in Turkey the main issue of discussion that relate to technology transfer is on parallel import, we have seen that there existed a confusion on which one of exhaustion of rights seem to have been approved in Turkey. Since having diverse outcomes are unacceptable, it was seen imperative to accept one of them in order to arrive at uniform decisions. Considering Turkey being in Customs Union with the EU, together with the fact that international agreements it has entered, and its trade relationships and rules being affirmative of parallel import, we came to the conclusion that the adoption of the international exhaustion of rights principle appears more appropriate.

Finally, the situation concerning the technology transfer issue in Turkey, the new technology transfer block exemption regulation should entail the necessary modifications made in the EU, address the question of the parallel import correctly in working together with the related institutions, like the Turkish Patent Institute (TPI). There are also other factors to be considered in developing a new technology transfer regulation, but since our area of interest in this study is the principle of exhaustion of rights only, we are focusing on the necessary arrangements related to this particular subject. The issuance of the technology transfer block exemption regulation is considered to fill an important gap in the area of innovative efforts coming into Turkey.

Exhaustion of rights and parallel import in Turkey is an area that causes confusion, which needs to be resolved before a technology transfer block exemption regulation is formulated. Because of this and due to the wide differences in points of view and judgments, this has been the subject of much discussion.

After the failure to launch a new round of trade liberalisation in Seattle in late 1999, the EU pushed for the rapid preparation of another multilateral trade round and reiterated that it is still aiming for a broad agenda ${ }^{27}$ in the new round. Supported by the EU's extensive consensus building efforts with other WTO members, in particular developing and least-developed countries, its modified approach to the new round ${ }^{28}$ was certainly one element in securing support for the launch of a new round of trade negotiations at the fourth Ministerial Conference at Doha in November 
2001. The far-reaching conclusions of the Doha Conference and resulting a broad DDA reflect very well the EU's overall objectives for the multilateral trade round ${ }^{29}$ and its acknowledgement of a broad agenda for the round. The EU also supported an early start to negotiations in the WTO on multilateral basis for international investment and competition policy, which have become increasingly important in underpinning effective market access in increasingly integrated world. Moreover, the EU supported the fact that developing countries would need to be better integrated into the system and have freer market access. For example, the EU participated in the confidence building package extending duty free access for essentially all the least-developed country imports in the hope of tempting developing countries to join a new round. These all mean that the EU acted as an emerging leader in support of multilateralism in general and for its interests in particular during the preparations for the DDR. Now, it is more crucial than ever before for the future of multilateralism that the EU must continue to act as WTO-custodian and conclude the trade talks successfully.

In the sixth TPR of the $\mathrm{EU}^{30}$, the Chairperson concluded that members of the WTO acknowledged the leadership role of the EU in the WTO notably in securing agreement on the DDR, thus demonstrating its support for an open, rules-based multilateral trading system. ${ }^{31}$ Therefore, the continued commitment of the EU will be critical to the success of the DDR. Accordingly, the EU in its report stated that it will continue to work to reinforce the WTO, to enlarge and improve its system and to promote a more active participation of all its members. The EU sees as its immediate task to carry out multilateral negotiations in a way that reflects the objectives of the DDA and the EU's own goals.

\section{Sonnotlar}

${ }^{1}$ Green, N. \& Robertson, A. (1997). Commercial Agreements and Competition Law. London: Kluwer Law International, p 13

${ }^{2}$ Albert, F. \& Heath, C. (1997). "Dyed But Not Exhausted: Parallel Imports and Trade Marks in Germany". IIC, p.29.

${ }^{3}$ Arıkan, A.S. (2002). "Fikri ve Sinai Hakların Tükenmesi ve Rekabet Hukuku". Uluslararası Hukuk Kurultayı 2002. Ankara, p.754.

${ }^{4}$ Ibid 
${ }^{5}$ Ibid. p.759

${ }^{6}$ Kayhan, F., (2001). "Parallel İthalat ve Marka Hakkının Tükenmesi" FMR, Cilt 1, Say1 2001-1, Ankara, p.62

${ }^{7}$ Okutan, G.,(Tekinalp/Tekinalp) (2000). "Topluluk Hukukunda Fikri Mülkiyet Haklan” Avrupa Birliği Hukuku, İstanbul. Beta, 2.bası, p.686

${ }^{8}$ Kayhan, F., (2001). "Parallel İthalat ve Marka Hakkının Tükenmesi" FMR, Cilt 1 , Say1 2001-1, Ankara, p.62

${ }^{9}$ Pınar, H. (2004). “Fikri Mülkiyet Hukuku ve Rekabet Hukuku”. Türkiye AB İlşkileri Işı̆gnda Rekabet Hukuku Güncel Sorunlan Kolokyumu. İstanbul: 14 Ekim, p.28

${ }^{10}$ Ibid, pp.28-29

${ }^{11}$ Ibid, p.29

${ }^{12}$ Ibid, pp.29-30

${ }^{13}$ Y.11.HD.T.12.3.1999, Competition Board Decision 00-44/472-257,6.11.2000

${ }^{14}$ 26.5.1999t. E.1999/2086, K. 1999/4505

${ }^{15}$ Pınar, H. (2004). "Fikri Mülkiyet Hukuku ve Rekabet Hukuku”. Türkiye AB İlşkileri Işığında Rekabet Hukuku Güncel Sorunlan Kolokyumu. İstanbul: 14 Ekim, pp.47-48

${ }^{16}$ Competition Board Decision 01-25/238-61, 29.5.2001

${ }^{17}$ Pınar, H. (2004). "Fikri Mülkiyet Hukuku ve Rekabet Hukuku”. Türkiye AB İlşkileri Işı̆̆ında Rekabet Hukuku Güncel Sorunlan Kolokyumu. İstanbul: 14 Ekim, p.50

${ }^{18}$ Aslan, Y. (2001). "Endüstriyel Tasarım Haklarının Kullanılması: Haksız Rekabet ve Rekabet Hukuku İlşkileri: Bir Mahkeme Kararı Üzerine Düşünceler”. FMR. Issue 1. Ankara: Ankara Barosu Dergisi, p.347

${ }^{19}$ Ibid, p.347 and p.351

${ }^{20}$ Ibid, p. 352

${ }^{21}$ lbid, p. 173

${ }^{22}$ Tekinalp, Ü. (1999). Fikri Mülkiyet Hukuku. İstanbul: Beta, p.417

${ }^{23}$ Aslan, Y. (2001). "Endüstriyel Tasarım Haklarının Kullanılması: Haksız Rekabet ve Rekabet Hukuku İlşkileri: Bir Mahkeme Kararı Üzerine Düşünceler”. FMR.

Issue 1. Ankara: Ankara Barosu Dergisi, p.353 
${ }^{24}$ Pınar, H. (2004). "Fikri Mülkiyet Hukuku ve Rekabet Hukuku”. Türkiye AB İlşkileri Işı̆ginda Rekabet Hukuku Güncel Sorunlarn Kolokyumu. İstanbul: 14 Ekim, p.52

${ }^{25}$ Whish, R. (2001). Competition Law. Fourth Edition. Bath UK: Butterworths, p.709

${ }^{26}$ Ibid, p.710

${ }^{27}$ The EU acknowledged that only a broad agenda could both reconcile different members' views and take into account of all members' essential interests.

${ }^{28}$ Drawing from the lessons of the Seattle Conference, which failed to launch a new round, the EU adapted its approach to the new round, in particular by recognising that the WTO needed to work in a more inclusive and transparent way vis-à-vis all members, and improve communication with the outside world. On the substance of the lessons drawn from Seattle, the EU took into consideration other members' opinions and continued bridge building efforts with trading partners in order to overcome differences.

WTO (2002), Trade Policy Review, European Union, Geneva.

${ }^{29}$ A fourfold agenda to further liberalise market access, to update and improve WTO rules, to promote a development agenda and to address issues of public concern.

${ }^{30}$ WTO, 2002.

${ }^{31}$ The review is based on two reports that are prepared respectively by the WTO Secretariat and the government under review (in this case the EU) and which cover all aspects of the country's trade policies. A record of the discussion and the Chairperson's summing-up together with these two reports were published at the complete TPR of the EU. 